\title{
Alternative Arable Cropping Strategies: A Key to Enhanced Productivity, Resource-Use-Efficiency, and Soil-Health under Subtropical Climatic Condition
}

\author{
R.K. Naresh ${ }^{1 *}$, Ashok Kumar ${ }^{2}$, Mukesh Kumar ${ }^{3}$, Vivek ${ }^{1}$, P.K. Singh ${ }^{4}$, \\ Manoj Kumar Singh ${ }^{3}$, S.P. Singh ${ }^{2}$ and Vivak Ujjwal ${ }^{3}$ \\ ${ }^{1}$ Department of Agronomy, ${ }^{2}$ Department of Soil Science, \\ ${ }^{3}$ Department of Horticulture, ${ }^{4}$ Krishi Vigyan Kendra, Beghra, Sardar Vallabhbhai Patel \\ University of Agriculture and Technology, Meerut-250110, U.P., India \\ *Corresponding author
}

\begin{tabular}{l} 
K e y w o r d s \\
$\begin{array}{l}\text { Profitability, Soil } \\
\text { health, Energy } \\
\text { relationships, } \\
\text { Resource use } \\
\text { efficiency. }\end{array}$ \\
\hline Article Info \\
$\begin{array}{l}\text { Accepted: } \\
12 \text { September } 2017 \\
\text { Available Online: } \\
10 \text { November } 2017\end{array}$ \\
\hline
\end{tabular}

\section{Introduction}

Rice - wheat is the most dominant crop sequence in the sandy loam soil region of western Uttar Pradesh, India. Continuous cultivation of rice-wheat for longer periods with low system productivity, and often with poor crop management practices, results in loss of soil fertility due to emergence of multiple nutrient deficiency (Dwivedi et al.,
2001) and deterioration of soil physical properties (Tripathi, 1992), and decline in factor productivity and crop yields in high productivity areas (Yadav, 1998). During cultivation of rice soil undergoes drastic changes, i.e. aerobic to anaerobic environment, leading to several physical and electro-chemical transformations. Puddling 
breaks capillary pores, reduces void ratio, destroys soil aggregates, disperses fine clay particles, and lowers soil strength in the puddled layer (Sharma and De Datta, 1986). In systems that are frequently wet and dry, there is potential for significant loss of $\mathrm{N}$ by leaching and denitrification. Further, since nitrite is an intermediate in both the reduction of nitrate and the oxidation of ammonia, aerobic denitrification via nitrate may be more substantial and widespread than previously realized, especially on soils that are alternately wet and dry (Ponnamperuma, 1972).

Cassman et al., (1995) proposed that the now commonly observed, smaller than previous response to $\mathrm{N}$ fertilizer in continuously flooded rice systems, is associated with sequestration of $\mathrm{N}$ in resistant lignin compounds formed from the large amounts of retained crop residues. If this is the case, then perhaps there is an important role for rice rotations that include upland crops, such as wheat and grain legumes, to break this sequestration of $\mathrm{N}$. Diversification and intensification of rice-based system to increase productivity per unit resource is very pertinent. Crop diversification shows lot of promises in alleviating these problems besides, fulfilling basic needs for cereals, pulses, oilseeds and vegetables and, regulating farm income, withstanding weather aberrations, controlling price fluctuctuation, ensuring balanced food supply, conserving natural resources, reducing the chemical fertilizer and pesticide loads, ensuring environmental safety and creating employment opportunity (Gill and Ahlawat, 2006). Alternative cropping has been recognized as an effective strategy for achieving the objectives of food security, nutrition security, income growth, poverty alleviation, employment generation, and judicious use of land and water resources, sustainable agricultural development and environmental improvement (Hedge et al., 2003). The Alternative cropping crop may enhance profitability, reduce pests, spread out labour more uniformly, reduce risks from aberrant weather by different planting and harvesting times and source of high value products from new crops (Reddy and Suresh, 2009). In the era of shrinking resource base of land, water and energy, resource use efficiency an important aspect for considering the suitability of a cropping system (Yadav, 2002). Hence, selection of component crops needs to be suitably planned to harvest the synergism among them towards efficient utilization of resource base and to increase overall productivity (Anderson, 2005).

There is ample scope to diversify Kharif rice with maize, as it has significantly lower irrigation requirement than rice and can enhance the system productivity and sustain soil health and environment quality Singh, 2012. On the other hand, vegetable cowpea is emerging as an alternate option in Kharif season being a high-value legume to enhance farm profitability and soil health as well (Kalia and Kumar, 2012). Onion prices in south-Asia particularly India are relatively high in the months of October-November due to less supply and production in the region and to curtail this price rise, Kharif onion production has great potential in western Uttar Pradesh as mid-term strategy (Gupta, 2013). The area under rainy-season onion crop in India is about $20 \%$ of the total cultivated area; thus, Kharif onion production in non-traditional areas would definitely ensure the availability, price-stabilization and better remunerations to practicing farmers (Choudhary et al., 2013 and Gupta, 2013). Green-chilli is another viable option in Kharif season to meet the peri-urban demand and reap high economic returns (Dey et al., 2012). Potato is a short duration high value cash crop with flexible sowing-window which could be 
another suitable crop-intensification alternative, besides enhancing farm productivity and profitability (Sharma and Sharma, 2005). Short-duration summerlegume crop mungbean (Phaseolus radiatus L.) in western Uttar Pradesh has great potential in enhancing crop-intensification and thus, harnessing better system productivity and profitability (Sharma and Sharma, 2004). Inclusion of mungbean and its' residue incorporation after harvesting of pods is added advantage of $\mathrm{N}$-fixing for resilience soil fertility (Pooniya et al., 2012, and (Sharma and Sharma, 2004).

Overall, alternative cropping strategy in cereal-based production systems is the need of the hour in western Uttar Pradesh both through location-specific cereal replacement and crop-intensification as well (Singh et al., 2011 and Singh, 2012). Therefore, the present investigation was conductively undertaken to diversify the cereal-based production systems with productive, resource-use-efficient and remunerative with appropriate and promising vegetable and legume-based systems viz. ricewheat $(\mathrm{R}-\mathrm{W})$, rice-potato- mungbean (R-P$\mathrm{M}_{\mathrm{b}}$ ), rice-cabbage-onion (R-C-O), maizewheat- mungbean (M-W-M $\mathrm{M}_{\mathrm{b}}$ ), maize-potatomungbean (M-P-M $\mathrm{M}_{\mathrm{b}}$ ), maize-potato-onion (M$\mathrm{P}-\mathrm{O})$,maize-garlic-mungbean $\quad\left(\mathrm{M}-\mathrm{G}-\mathrm{M}_{\mathrm{b}}\right)$, cowpea-potato-mungbean $\left(\mathrm{C}-\mathrm{P}-\mathrm{M}_{\mathrm{b}}\right)$, Kharif onion-wheat-mungbean $\left(\mathrm{O}-\mathrm{W}-\mathrm{M}_{\mathrm{b}}\right)$, and chilli-wheat-mungbean $\quad\left(\mathrm{C}_{\mathrm{h}}-\mathrm{W}-\mathrm{M}_{\mathrm{b}}\right)$ to enhance system productivity, profitability and resources use- efficiency; besides ameliorating the production vulnerabilities that RWCS has brought so far.

\section{Materials and Methods}

An experiment on alternative arable cropping strategies was conducted during Kharif (wet season), Rabi (dry season) and summer season of the year 2010-111 to 2014-15 in farmers participatory mode in the jurisdiction of the Sardar Vallabhbhai Patel University of Agriculture and Technology, Meerut U.P. India., $\left(28^{\circ} 402073 \mathrm{~N}\right.$ to $29^{\circ} 282113 \mathrm{~N}$, $77^{\circ} 282143 \mathrm{E}$ to $\left.77^{\circ} 44183 \mathrm{E}\right)$ and was designed as a farmer-managed with a single replicate, repeated over many farmers. Therefore, the experimental design was Randomized Block Design in which farmer as a replicate/ block. The climate of the region is broadly classified as semi-arid sub-tropical, characterized by very hot summers and cold winters. The hottest months are May and June when the maximum temperature reaches 45$46^{\circ} \mathrm{C}$, while in December and January, the coldest months of the year, the minimum temperature often goes below $4^{\circ} \mathrm{C}$. Average annual rainfall is $805 \mathrm{~mm}, 80 \%$ of which is received through the north-western monsoon during June-September. Important characteristics of the $0-15 \mathrm{~cm}$ soil layer of the experimental field are presented in Table 1.

\section{Experimental details}

The experiment was laid-out in designed as a farmer-managed with a single replicate, repeated over many farmers. Therefore, the experimental design was Randomized Block Design in which farmer as a replicate/ block. Treatments comprised of ten alternative arable cropping strategies viz. rice-wheat (R$\mathrm{W})$, rice-potato- mungbean $\left(\mathrm{R}-\mathrm{P}-\mathrm{M}_{\mathrm{b}}\right)$, ricecabbage-onion (R-C-O), maize-wheatmungbean $\left(\mathrm{M}-\mathrm{W}-\mathrm{M}_{\mathrm{b}}\right)$, maize-potatomungbean (M-P-M $\mathrm{M}_{\mathrm{b}}$ ), maize-potato-onion (M$\mathrm{P}-\mathrm{O})$, maize-garlic-mungbean $\left(\mathrm{M}-\mathrm{G}-\mathrm{M}_{\mathrm{b}}\right)$, cowpea-potato-mungbean $\left(\mathrm{C}_{\mathrm{p}}-\mathrm{P}-\mathrm{M}_{\mathrm{b}}\right)$, onionwheat-mungbean $\left(\mathrm{O}-\mathrm{W}-\mathrm{M}_{\mathrm{b}}\right)$, and chilliwheat-mungbean $\quad\left(\mathrm{C}_{\mathrm{h}}-\mathrm{W}-\mathrm{M}_{\mathrm{b}}\right) \quad$ cropping systems were taken with recommended dose of fertilizers. The details of crops and field cultural operations followed in cropping systems etc. are given in Table 2. A common dose of nutrients amounting $150 \mathrm{~kg} \mathrm{~N}+60 \mathrm{~kg}$ $\mathrm{P}_{2} \mathrm{O}_{5}+40 \mathrm{~kg} \mathrm{~K}_{2} \mathrm{O}+25 \mathrm{~kg} \mathrm{ZnSO}_{4} \mathrm{ha}^{-1}$ were applied in all treatments during first year of 
study (2010-11). The $1 / 3^{\text {rd }} \mathrm{N}$ and whole $\mathrm{P}_{2} \mathrm{O}_{5}$, $\mathrm{K}_{2} \mathrm{O}$ and $\mathrm{ZnSO}_{4}$ was applied as basal, while remaining $2 / 3^{\text {rd }} \mathrm{N}$ was top dressed as urea in two equal splits at two vegetative growth phases.

At the time of top dressing, fertilizer was broadcasted and care was taken so that the fertilizers were mainly applied on targeted crop rows only. Proper agronomic practices were followed during crop growth periods. At maturity, the crop was harvested manually and estimates the grain yield. Grain moisture was determined using a grain moisture meter. The grain yield of crops was adjusted at 14\% moisture content.

\section{Soil chemical and physical analysis}

After drying, the soil samples were drawn for chemical analysis. The available N, P and K were determined using standard procedures mentioned in Table 1. Bulk density of surface $(0-15 \mathrm{~cm})$ and sub-surface $(15-30 \mathrm{~cm})$ soil was determined by the core sampler method from three randomly chosen spots from each plot (Chopra and Kanwar, 1991). The soil porosity was computed from the relationship between bulk density and particle density using (1):

Porosity $(\%)=1-\frac{\mathrm{BD}}{\mathrm{PD}} \times 100$

Where

BD is bulk density $\left(\mathrm{g} \mathrm{cm}^{-3}\right)$, and

$\mathrm{PD}$ is particle density $\left(\mathrm{g} \mathrm{cm}^{-3}\right)$

\section{Soil organic carbon (SOC)}

Soil organic carbon was determined by wet digestion with potassium dichromate along with $\quad 3: 2 \quad \mathrm{H}_{2} \mathrm{SO}_{4}: \quad 85 \% \quad \mathrm{H}_{3} \mathrm{PO}_{4}$ digestion mixture in a digestion block set at $120^{\circ} \mathrm{C}$ for $2 \mathrm{~h}$ (Snyder and Trofymow, 1984).

\section{Total organic carbon (TOC)}

The TOC content was determined by using Walkley and Black's (1934) rapid titration method and computed using Eq. (2):

TOC stock $\left(\mathrm{Mg} \mathrm{C} \mathrm{ha}^{-1}\right)=$ TOC content $(\mathrm{g} \mathrm{C}$ $\left.\mathrm{kg}^{-1}\right) \times \mathrm{Db}\left(\mathrm{Mg} \mathrm{m}^{-3}\right) \times$ Soil layer $(\mathrm{m}) \times 10(2)$

Where,

$\mathrm{Db}$ is bulk density of the particular soil layer (Db values for $0-5 \mathrm{~cm}$ and $5-15 \mathrm{~cm}$ soil layer were 1.32 and $1.34 \mathrm{Mg} \mathrm{m}^{-3}$ ), respectively).

\section{Soil sampling for soil quality parameters}

Soil samples were taken from the experimental field randomly from each plot after the end of cropping system cycles during five years.

Ten soil cores $(5 \mathrm{~cm}$ diameter, $0-15 \mathrm{~cm}$ depth) were taken from each plot. The soil samples were put in polythene bags and allowed to dry and transported to the laboratory where they were thoroughly mixed and sieved ( $2 \mathrm{~mm}$ mesh).

The soil samples were then stored overnight at $5^{\circ} \mathrm{C}$ in the dark, and prior to biological analyses they were equilibrated to $22-25^{\circ} \mathrm{C}$ Pooniya et al., (2012). The micronutrients $(\mathrm{Zn}, \mathrm{Fe}$, and $\mathrm{Cu}$ ) were estimated using the method suggested by Lindsay and Norvell (1978) with inductively coupled plasma spectrophotometer (model ICP-OES XP, Australia.

\section{Measurement of enzyme activities}

To determine biological function changes in soil, some enzyme activities were determined by the procedures as described by the different scientists (Guan and Shen, 1984; Guan, 1986; 1989). (1) $\mathrm{Na}_{2} \mathrm{RPO}_{4}$ (R indicates 
benzene material) as the medium and measuring releasing content using the color comparison method $\left(\mathrm{P}_{2} \mathrm{O}_{5} \mathrm{mg} / 100 \mathrm{~g}, 37^{\circ} \mathrm{C}, 2\right.$ h) for Alkaline phosphatase. (2) Measuring $\mathrm{NH}_{3}-\mathrm{N}$ content $\left(\mathrm{NH}_{3}-\mathrm{N} \mathrm{mg} \cdot \mathrm{g}^{-1}, 37^{\circ} \mathrm{C}, 24 \mathrm{~h}\right)$ by the color comparison method, with urea as medium for urease. (3) Measuring glucose content (glucose $\mathrm{mg} \cdot \mathrm{g}^{-1}, 37^{\circ} \mathrm{C}, 24 \mathrm{~h}$ ) by the color comparison, glucose as the medium for sucrose by using Photo-spectrometer (Guan, 1986). (4) Acid phosphatase (EC 3.1.3.2) enzyme was measured using $p$-nitrophenyl phosphate disodium $(0.115 \mathrm{M})$ as substrate according to Mandal et al., (2007). (5) Dehydrogenase activity was determined by the reduction of triphenyl tetrazolium chloride (TTC) to triphenyl formazan (TPF) as described by Serra-Wittling et al., (1995). (6) Soil invertase activity was measured by incubating $5.0 \mathrm{~g}$ soil with $15 \mathrm{ml}$ of $8 \%$ sucrose solution for $24 \mathrm{~h}$ at $37^{\circ} \mathrm{C}$. The suspension reacted with 3, 5-dinitrosalicylic acid and absorbance was detected at $508 \mathrm{~nm}$. (7) Protease activity was assayed using the Ladd and Butler method (1972). All determinations of each sample were performed in triplicate, and all values reported are averages of the three determinations expressed on an ovendried soil basis.

\section{Economic analysis, production indices and monetary efficiencies}

In order to determine the cost of cultivation, cost of each input and output were calculated accordingly as per prevailing prices during each year. Gross and net returns per ha were calculated based on the crop productivity and prevailing market prices of different crops during respective crop years/seasons. The system productivity and profitability was calculated by dividing the crop equivalent yield and net returns by 365 . The irrigation system productivity was calculated by dividing the crop equivalent yield by the total amount of irrigation water was used to grow the crop (Katyal and Gangwar 2011). Similarly, nutrient use productivity was calculated by dividing the crop equivalent yield by the total quantity of nutrients used in the cropping system. Total system energy input and output was measured based on energy input/output of each crop in respective system. Physical energy of each input and output was converted into energy equivalents viz. Mega Joules (MJ) and Giga Joules (GJ) by using conversion coefficient values given by Gopalan et al., 1978. Energy input-output relationship with respect to energy efficiency, energy productivity and net energy in different cropping systems vary with the component crops knitted in a cropping sequence,soil type, agronomic operations and fertilizers used, plant protection measures and economic produce levels Mandal et al., 2005.

\section{Statistical analysis}

All the field and laboratory data on various plant parameters on component crops of different cropping systems was statistically analyzed using the $\mathrm{F}$ test as per the procedure given by Gomez and Gomez (1984). Least significance difference (LSD) values at $\mathrm{P}=$ 0.05 were used to determine the significant differences between treatment me

\section{Results and Discussion}

\section{Production efficiency and land use efficiency}

Present experiment revealed that among ten alternative arable cropping systems (AACS) viz. M-P-O, M-G-M $-M_{b}, R-P-M_{b}, O-W-M_{b}$ and $\mathrm{C}_{\mathrm{h}}-\mathrm{W}-\mathrm{M}_{\mathrm{b}}$ recorded highest production efficiency followed by M-P-M $\mathrm{M}_{\mathrm{b}}, \mathrm{C}_{\mathrm{p}}-\mathrm{P}-\mathrm{M}_{\mathrm{b}}$ and R-C-O, respectively (Table 3). High production potential of garlic, potato, onion and higher pod yield in cowpea and mungbean, were the possible reasons for getting highest efficiency in this system. 
Potato/Onion/Garlic based systems are also more productive and profitable than cerealbased systems due to higher productivity resulting in better remuneration. This discussion holds true in the current study, when highest production efficiency in M-G$\mathrm{M}_{\mathrm{b}}$ was reflected due to residual fertility of legumes tailored in this system (Singh et al., 2011) besides higher supply of macro and micronutrients and soil physical health (Table 5 and 6), due to better phosphatase and dehydrogenase activity by incorporating the SMB biomass (Banik and Sharma, 2009). The land use efficiency under M-P-O, M-G-M R-P-M $\mathrm{M}_{\mathrm{b}}, \mathrm{M}-\mathrm{P}-\mathrm{O}$, and M-P-M $\mathrm{b}$ was recorded as $85.1,84.8,84.6,83.4$ and $83.3 \%$, respectively which were at par with $\mathrm{C}_{\mathrm{p}}-\mathrm{P}-\mathrm{M}_{\mathrm{b}}$ (82.8\%), O-W-M $\mathrm{M}_{\mathrm{b}}$ system (81.5\%) and $\mathrm{C}_{\mathrm{h}}-\mathrm{W}$ $\mathrm{M}_{\mathrm{b}}(80.2 \%)$. However, energy value in terms of energy use ratio was only 3.09 over existing R-W system (8.38), respectively.

\section{Energy dynamics and energy use efficiencies}

Keeping in view current energy crisis, studies on energy dynamics and energy use efficiency in agricultural production systems also assume great importance to identify promising production systems which have less dependency on non-renewable energy sources. In the current study, the estimation of energy use in different cropping systems revealed that $\mathrm{M}-\mathrm{P}-\mathrm{O}$ utilized highest energy (28.9 $\mathrm{GJ} \mathrm{ha}^{-1}$ ) followed by $\mathrm{C}_{\mathrm{p}}-\mathrm{P}-\mathrm{M}_{\mathrm{b}}(26.4 \mathrm{GJ}$ $\left.\mathrm{ha}^{-1}\right), \quad \mathrm{M}-\mathrm{P}-\mathrm{Mb}, \quad \mathrm{R}-\mathrm{P}-\mathrm{M}_{\mathrm{b}}$ and $\mathrm{O}-\mathrm{W}-\mathrm{M}_{\mathrm{b}}$, respectively. $\mathrm{M}-\mathrm{P}-\mathrm{O}$ system used highest energy input because potato consumes higher energy with respect to fertilizer, seed as well as human labour for earthing-up and digging operations in potato; besides more energy input in pod picking operation both in cowpea and mungbean legumes. $\mathrm{C}_{\mathrm{h}}-\mathrm{W}-\mathrm{Mb}$ and $\mathrm{R}-\mathrm{C}$ $\mathrm{O}$ sequence also consumed more energy owing to regular spraying of pesticides in chilli crop being prone to wet season diseases besides relatively higher fertilizer and irrigation requirements in chilli and cabbage (Singh et al., 2011. M-G-M $\mathrm{M}_{\mathrm{b}}, \mathrm{C}_{\mathrm{p}}-\mathrm{P}-\mathrm{M}_{\mathrm{b}}$ and $\mathrm{M}-\mathrm{P}-\mathrm{O}$ systems again exhibited higher energy efficiency because in spite of better energy output by these systems, their energy use per unit energy output was quite lower as compared to other two systems. $\mathrm{C}_{\mathrm{h}}-\mathrm{W}-\mathrm{M}_{\mathrm{b}}, \mathrm{O}-$ $\mathrm{W}-\mathrm{M}_{\mathrm{b}}$ system also produced higher energy equivalents which resulted in greater net energy returns quite close to $\mathrm{C}_{\mathrm{p}}-\mathrm{P}-\mathrm{M}_{\mathrm{b}}$ system was primarily due to higher yield of this system.

\section{Production, monetary and employment efficiencies}

Production and monetary efficiencies are the performance indicators of various cropping systems in terms of productivity and monetary gains day $^{-1} \mathrm{ha}^{-1}$, respectively. In current study, highest production efficiency $\left(89.7 \mathrm{kgha}^{-1} \mathrm{day}^{-1}\right)$ and monetary efficiency (Rs. 351.6 ha $^{-1}$ day $^{-1}$ ) were observed in M-P-O which proved significantly superior over rest of the cropping systems (Table 4). M-P-M $\mathrm{M}_{\mathrm{b}}$ system ranked second and showed superiority over $\mathrm{M}-\mathrm{W}-\mathrm{M}_{\mathrm{b}}$ and $\mathrm{C}_{\mathrm{p}}-\mathrm{P}-\mathrm{M}_{\mathrm{b}}$. Overall, $\mathrm{M}-\mathrm{G}-$ $\mathrm{M}_{\mathrm{b}}$ cropping system utilized land more efficiently which led to higher production and monetary advantages in the present experimentation. Production efficiency referred as per day productivity of a system under particular treatment depends on production potential of crops taken in that system. Thus, highest production efficiency was observed in $\mathrm{C}_{\mathrm{p}}-\mathrm{P}-\mathrm{Mb}$ sequence because of highest production and gross returns obviously with considerable contributions of cowpea and potato crops. High value crops viz. onion, chilli, garlic, carrot, mungbean and cowpea producing quick returns, are perfect option for small holders to utilize surplus labour and augment their income. The remunerative price from onion resulted in higher net returns in $\mathrm{O}-\mathrm{W}-\mathrm{Mb}$ sequence but 
higher cost of cultivation is the major drawback for lower benefit: ratio than M-W$\mathrm{M}_{\mathrm{b}}$ rotation.

The data given in Table 3 and 4 revealed that there is sufficient scope to replace rice-wheat cropping system with other cropping systems without any decline in economic yield rather it improved substantially. The M-P-O; $\mathrm{C}_{\mathrm{p}}-\mathrm{P}-$ $\mathrm{M}_{\mathrm{b}}, \mathrm{M}-\mathrm{P}-\mathrm{M}_{\mathrm{b}}, \mathrm{M}-\mathrm{W}-\mathrm{M}_{\mathrm{b}}, \mathrm{M}-\mathrm{G}-\mathrm{M}_{\mathrm{b}}$ and R-C-O gave $2.1,1.8,1.7,1.5,1.3$ and 1.1 times more productivity over R-W system which clearly elucidated the superiority of these systems over R-W system. These systems also helped to save $83-116 \mathrm{~cm}$ of irrigation water (Table 3). The M-P-O system gave the highest productivity $\left(89.7 \mathrm{kgha}^{-1} \mathrm{day}^{-1}\right)$ and used $83 \mathrm{~cm}$ less water than R-W system with a productivity margin of $39.97 \mathrm{kgha}^{-1} \mathrm{day}^{-1}$. The summer $\mathrm{C}_{\mathrm{p}}-\mathrm{P}-\mathrm{M}_{\mathrm{b}}$ system gave $83.3 \mathrm{kgha}^{-1} \mathrm{day}^{-1}$ productivity with $115 \mathrm{~cm}$ irrigation water (Table 3 and 4) leading to $103 \mathrm{~cm}$ saving of water. M-P-M $\mathrm{M}_{\mathrm{b}}$ cropping system gave $88.6 \mathrm{kgha}^{-1}$ day $^{-1}$ productivity with total irrigation water used as $110 \mathrm{~cm}$, thereby indicating the net saving of irrigation water to the extent of $108 \mathrm{~cm}$.

The M-W-M $\mathrm{M}_{\mathrm{b}}$ produced $81.2 \mathrm{kgha}^{-1} \mathrm{day}^{-1}$ productivity and used only $102 \mathrm{~cm}$ irrigation water which was 53.2 per cent less than irrigation water used for R-W system (Table 3 $\& 4)$. It might be due to the reason that cowpea and mungbean pulse crops have improved the soil physicochemical properties which might have reduced the water loss due to evaporation, percolation and seepage as compared to R-W system (Singh and Malhotra, 2013; Chaudhary et al., 2006). The net returns were maximum Rs. 1, 54, $030 \mathrm{ha}^{-1}$ annum $^{-1}$ in M-P-O system and it was 2.61 times more over R-W system (Table 4). The net returns in the other cropping systems like $\mathrm{M}-\mathrm{W}-\mathrm{M}_{\mathrm{b}}, \mathrm{M}-\mathrm{G}-\mathrm{M}_{\mathrm{b}}, \quad \mathrm{M}-\mathrm{P}-\mathrm{M}_{\mathrm{b}}$ and $\mathrm{C}_{\mathrm{p}}-\mathrm{P}-\mathrm{M}_{\mathrm{b}}$ were Rs. 86,410, 123,933, 126,689 and 138,050 , respectively. The quantity of water used in the Ch-W-M, M-G-M, R-C-O, $\mathrm{C}_{\mathrm{p}}-\mathrm{P}-$ $\mathrm{M}_{\mathrm{b}}$ and $\mathrm{M}-\mathrm{P}-\mathrm{M}_{\mathrm{b}}$ was 32.1, 39.4, 44.9, 47.2 and 49.5 per cent less than quantity of water used for R-W system. The corresponding value in terms of saving of electricity consumption (per ha basis) was 628, 773, 883, 928 and 968 electricity units with electricity bill amounting Rs 3140, 3865, 4415, 4640 and 4840 per ha over R-W system, respectively (Table 4 ). The $\mathrm{C}_{\mathrm{p}}-\mathrm{P}-\mathrm{M}_{\mathrm{b}}$ system showed the highest water productivity of $2.325 \mathrm{~kg}$ grainm-3 irrigation water followed by M-G-M $\mathrm{M}_{\mathrm{b}}$ and M-P-O (2.216; $2.149 \mathrm{~kg}_{\text {grain }} \mathrm{m}^{-3}$ irrigation water). The least water productivity of $0.635 \mathrm{~kg}$ grain $\mathrm{m}^{-3}$ irrigation water was observed in R-W cropping system. Similar kinds of reports have also been reported by Bohra et al., (2007); Gill and Sharma (2005).

\section{Resource use efficiency}

In the present context of degradation of natural resources and the productivity of crops, the resources efficiency and sustainability of cropping systems are attracting the attention of scientists all over the world. The resources efficiency is a paramount character for the establishment of new cropping system. The cropping system which utilize the farmer's available resources effectively and provide him employment throughout that will be acceptable to the farmers readily. Resource use efficiency of different cropping systems was evaluated through different approaches proposed by Singh et al., (1990); Sharma (2002). Two components i.e. monetary return use efficiency (MRUE) Rs ha ${ }^{-1}$ day $^{-1}$ and system profitability ( $\mathrm{Rs} \mathrm{ha}^{-1} \mathrm{day}^{-1}$ ) were measured to analyze the efficiency of different cropping systems. The monetary return use efficiency (MRUE) values ranged between 163.9 and 351.6 among alternative arable cropping systems; being lowest in R-W and highest in M-P-O (Table 4). The monetary return use 
efficiency (MRUE) was above 48 in M-P-O, $\mathrm{M}-\mathrm{G}-\mathrm{M}_{\mathrm{b}}$ and $\mathrm{C}_{\mathrm{p}}-\mathrm{P}-\mathrm{M}_{\mathrm{b}}$ cropping systems. The system profitability among different cropping systems ranged between Rs. 176.8 and 388.9 ha $^{-1}$ day $^{-1}$. The system profitability efficiency like production efficiency was highest in M$\mathrm{P}-\mathrm{O}$ and it was distinctly higher than all other cropping systems. The system profitability efficiency was around Rs.320 ha $^{-1}$ day $^{-1}$ in M$\mathrm{W}-\mathrm{M}_{\mathrm{b}}, \quad \mathrm{M}-\mathrm{G}-\mathrm{M}_{\mathrm{b}}, \quad \mathrm{M}-\mathrm{P}-\mathrm{M}_{\mathrm{b}}$ and $\mathrm{C}_{\mathrm{p}}-\mathrm{P}-\mathrm{M}_{\mathrm{b}}$ cropping systems (Table 4).

Different cropping systems paid opportunities to the farmers to work for different number of days in a year, in agriculture there is a major problem of under employment and therefore, employment generation efficiency (EGE) cope with the cropping system which employs farmers for more number of days is a boon to the farmers. M-P-O engages farmers almost throughout the year i.e. 1.73 man day $\mathrm{ha}^{-1}$ day $^{-1}$, while $\mathrm{C}_{\mathrm{h}}-\mathrm{W}-\mathrm{M}_{\mathrm{b}}$ and $\mathrm{C}_{\mathrm{p}}-\mathrm{P}-\mathrm{M}_{\mathrm{b}}$ employs farmers for only 1.68 and 1.65 man day ha ${ }^{-1}$ day $^{-1}$. Almost all cropping systems do not engage farmers for more than 0.64 man day $\mathrm{ha}^{-1}$ day $^{-1}$ and it reflects under-employment in agriculture (Table 4). These data indicate that the farmers must go for agri-business along with raising cropping. These results corroborate the findings of Gangwar and Baldev (2005), Chandrappa et al., (2005), Bastia et al., (2008), Sharma et al., (2007).

\section{Soil fertility status}

$\mathrm{C}-\mathrm{P}-\mathrm{Mb}$ sequence exhibited higher value of soil available- N, P and $\mathrm{K}$ analyzed after 5 years of the sequence (Table 5); which might be due to incorporation of mungbean residues and inclusion of another legume cowpea having relatively higher above ground leaf biomass and below ground root biomass additions. Thus, higher root and shoot biomass additions might also be possible reasons for higher $\mathrm{OC}$ in $\mathrm{C}_{\mathrm{p}}-\mathrm{P}-\mathrm{M}_{\mathrm{b}}$ cropping system (Dwivedi et al., 2003; Sharma and Sharma, 2004). The available N-status monitored after 5 years of cropping systems indicated the improvement in $\mathrm{N}$ status over its initial value $\left(165.8 \mathrm{~kg} \mathrm{ha}^{-1}\right)$. The lowest $\mathrm{N}$ status was recorded in R-W cropping system $\left(162.8 \mathrm{kgha}^{-1}\right)$. The M-P-M $\mathrm{b}$ and M-P-O being input intensive high yielding systems showed comparatively better levels of available nitrogen but these were also found in the low category (Table 5). These results are in agreement with the findings of Idnani and Singh (2008).

$\mathrm{C}_{\mathrm{p}}-\mathrm{P}-\mathrm{M}_{\mathrm{b}}$ exhibited lower available $\mathrm{K}$ in soil over other sequences because potato is a heavy feeder of $\mathrm{K}$ and a good crop of potato removes about $250 \mathrm{~kg} \mathrm{~K} \mathrm{ha}{ }^{-1}$. On the contrary, $\mathrm{M}-\mathrm{W}-\mathrm{M}_{\mathrm{b}}$ system exhibited highest available $\mathrm{K}$ in soil because potato and Kharif onion imbedded cropping systems remove higher amounts of K (Choudhary and Suri, 2014). Inclusion of legumes and in-situ incorporation of mungbean residues led to an increased $\mathrm{OC}$ and available $\mathrm{N}$. Beneficial effect of legume residues to better nutrient reserves and favorable buffering capacity besides enhancing bio-availability of $\mathrm{N}$ and native $\mathrm{P}$. It also releases organic colloids having higher cation exchange sites attracting $\mathrm{K}$ from applied $\mathrm{K}$ and non-labile pool onto exchangeable pool which ultimately favours available $\mathrm{K}$ status in soil (Lund and Doss, 1980). The maximum buildup of $\mathrm{K}$ was accrued in maize based cropping systems (203.2 to $207.9 \mathrm{kgha}^{-1}$ ). The lowest value was recorded in rice-wheat system $\left(185.8 \mathrm{kgha}^{-1}\right)$ which was $11.9,11.811 .2$ and 9.4 per cent lower than M-P-O, M-G-M $\mathrm{W}-\mathrm{M}_{\mathrm{b}}$ systems, respectively. These results are in agreement with the findings of Kumar et al., (2008). The differences in organic carbon (O.C.) content were observed in various cropping systems; being markedly higher in $\mathrm{C}_{\mathrm{p}}-\mathrm{P}-\mathrm{M}_{\mathrm{b}}, \quad \mathrm{M}-\mathrm{G}-\mathrm{M}_{\mathrm{b}}, \quad \mathrm{M}-\mathrm{P}-\mathrm{O}$ and $\mathrm{M}-\mathrm{P}-\mathrm{M}_{\mathrm{b}}$ cropping system. The organic carbon content in all the cropping systems increased over initial except R-W cropping system. 
Table.1 Physico-chemical properties of experimental soil at initiation of field experiment

\begin{tabular}{|c|c|c|}
\hline Soil parameters & Status/value & Methods employed \\
\hline \multicolumn{3}{|l|}{ Mechanical separates } \\
\hline Sand & 63.0 & \multirow[t]{3}{*}{ Modified hydrometer Bouyoucos, (1962) } \\
\hline Silt & 16.2 & \\
\hline Clay & 20.4 & \\
\hline Textural class & Sandy loam & \\
\hline \multirow[t]{2}{*}{ Bulk density $\left(\mathrm{Mg} \mathrm{m}^{-3}\right)$} & $1.40(0-15 \mathrm{~cm})$ & \multirow[t]{2}{*}{ Core sampler } \\
\hline & $1.46(15-30 \mathrm{~cm})$ & \\
\hline $\begin{array}{l}\text { Water stable } \quad \text { aggregates } \\
(>0.25 \mathrm{~mm})\end{array}$ & 48.5 & Wet sieving Haynes, (1993) \\
\hline Moisture at field capacity (\%) & 15.5 & \\
\hline \multicolumn{3}{|l|}{ Soil chemical properties } \\
\hline Soil reaction $\left(\mathrm{P}^{\mathrm{H}}\right)$ & 7.5 & 1:2.5 soil \& water suspension Jackson, (1967) \\
\hline Organic carbon $(\%)$ & 0.36 & Rapid titration method Walkley and Black (1934) \\
\hline \multicolumn{3}{|l|}{$\left.{ }_{1}\right) \quad$ Available nutrients $\left(\mathrm{kg} \mathrm{ha}^{-}\right.$} \\
\hline $\mathrm{N}$ & 165.8 & $\begin{array}{l}\text { Alkaline permanganate method Subbiah and Asija } \\
\text { (1956) }\end{array}$ \\
\hline $\mathrm{P}$ & 12.5 & $0.5 \mathrm{M} \mathrm{NaHCO}_{3}, \mathrm{P}^{\mathrm{H}} 8.5$ Olson et al., (1954) \\
\hline K & 193.2 & Ammonium acetate Hanway and Heidel (1952) \\
\hline
\end{tabular}

Table.2 Details of agronomic practices followed for different crops in field experimentation during 2010-2011 to 2014-2015

\begin{tabular}{|c|c|c|c|}
\hline Crop in rotation & $\begin{array}{c}\text { Seed rate } \\
\mathrm{kg} \mathrm{ha}^{-1}\end{array}$ & Date of sowing/ transplanting & Date of harvesting \\
\hline Rice (Oryza sativa l) & 25 & 3rd week of June & 3rd week of October \\
\hline Wheat (Triticum aestivum L.) & 100 & 2nd week of November & 2nd week of April \\
\hline Maize (Zea mays L.) & 20 & 1st week of July & 2nd week of October \\
\hline Mungbean (Phaseolus radiatus L.) & 25 & 3rd week of April & 3rd week of June \\
\hline $\begin{array}{l}\text { Cowpea (Vigna unguiculata } \mathrm{L} . \\
\text { Walp.) }\end{array}$ & 30 & 1st week of July & 3 rd \& 4th week of Sept. \\
\hline Pearlmillet (Pennisetum glaucum) & $5-6$ & 2nd week of June & $\begin{array}{c}\text { 1Vth week of } \\
\text { September }\end{array}$ \\
\hline Potato (Solanum tuberosum L.) & 2000 & 3rd week of October & 1st week of March \\
\hline Cabbage (Brassica oleracea) & $\begin{array}{c}750-1000 \\
\mathrm{gm}\end{array}$ & $\begin{array}{l}\text { 3rd week of Sept. -1 st week of } \\
\text { Oct. }\end{array}$ & $\begin{array}{l}\text { 3rd \& 4th week of } \\
\text { October }\end{array}$ \\
\hline Kharif Onion (Allium cepa L.) & $4-5$ & 1st week of July & 1st week of November \\
\hline Garlic & $300-400$ & $\begin{array}{l}\text { lVth week of Sept. - 1st week of } \\
\text { Oct. }\end{array}$ & 1st week of March \\
\hline
\end{tabular}


Table.3 System efficiency and energy use pattern under alternative cropping systems

\begin{tabular}{|c|c|c|c|c|c|c|c|c|}
\hline $\begin{array}{c}\text { Crop } \\
\text { Sequences }\end{array}$ & $\begin{array}{l}\text { Duration of } \\
\text { crops (days) }\end{array}$ & $\begin{array}{c}\text { Land use } \\
\text { efficiency } \\
(\%)\end{array}$ & $\begin{array}{c}\text { Production } \\
\text { efficiency } \\
\left(\mathrm{kg}^{-1} \mathrm{ha}^{-1} \text { day }^{-}\right. \\
1)\end{array}$ & $\begin{array}{c}\text { Total input } \\
\text { energy } \\
\left(\text { GJha }^{-1}\right)\end{array}$ & $\begin{array}{c}\text { Specific } \\
\text { energy } \\
\left(\text { MJha }^{-1}\right)\end{array}$ & $\begin{array}{c}\text { Energy } \\
\text { use } \\
\text { ratio }\end{array}$ & $\begin{array}{c}\text { Net } \\
\text { energy } \\
\left(\text { GJ ha }^{-1}\right)\end{array}$ & $\begin{array}{c}\text { Irrigation } \\
\text { water applied } \\
\left(\mathrm{cm} \mathrm{ha}^{-1} \text { year }^{-}\right. \\
\left.\mathbf{1}^{-}\right)\end{array}$ \\
\hline $\mathrm{R}-\mathrm{W}$ & 256.6 & 70.4 & 16.1 & 21.2 & 3.91 & 8.38 & 42.9 & 218 \\
\hline R-P-M $\mathrm{b}_{\mathrm{b}}$ & 317.5 & 84.8 & 37.64 & 25.5 & 4.77 & 3.09 & 49.9 & 178 \\
\hline R-C-O & 310.1 & 83.3 & 31.36 & 23.8 & 3.95 & 3.63 & 50.1 & 120 \\
\hline $\mathrm{M}-\mathrm{W}-\mathrm{M}_{\mathrm{b}}$ & 297.8 & 76.3 & 29.80 & 21.9 & 4.13 & 3.77 & 46.8 & 102 \\
\hline M-P-M & 309.4 & 83.4 & 33.37 & 28.9 & 4.96 & 3.96 & 48.3 & 110 \\
\hline M-P-O & 311.7 & 85.1 & 38.86 & 25.7 & 5.71 & 3.85 & 50.8 & 135 \\
\hline $\mathrm{C}_{\mathrm{h}}-\mathrm{W}-\mathrm{M}_{\mathrm{b}}$ & 266.7 & 80.2 & 34.37 & 23.8 & 4.97 & 3.82 & 46.4 & 148 \\
\hline $\mathrm{O}-\mathrm{W}-\mathrm{M}_{\mathrm{b}}$ & 315.8 & 81.5 & 35.49 & 23.2 & 4.20 & 3.89 & 51.7 & 152 \\
\hline M-G-M & 289.6 & 84.6 & 38.18 & 23.1 & 5.02 & 3.84 & 61.7 & 132 \\
\hline $\mathrm{C}_{\mathrm{p}}-\mathrm{P}-\mathrm{M}_{\mathrm{b}}$ & 302.2 & 82.8 & 32.59 & 26.4 & 5.49 & 3.74 & 55.6 & 115 \\
\hline
\end{tabular}

Table.4 Efficiency of various crop sequences (mean of 5 cropping cycles)

\begin{tabular}{|c|c|c|c|c|c|c|c|c|}
\hline $\begin{array}{c}\text { Crop } \\
\text { Sequence } \\
\mathrm{s}\end{array}$ & $\begin{array}{c}\text { WUE } \\
\text { (kg grain/ } \\
\text { m }^{3} \text { water } \\
\text { used) }\end{array}$ & $\begin{array}{c}\text { Electric } \\
\text { consumptio } \\
n\end{array}$ & $\begin{array}{c}\text { Cost of } \\
\text { electricity } \\
\text { consumptio } \\
n\end{array}$ & $\begin{array}{c}\text { MRUE } \\
\text { (Rs/ha/da } \\
\text { y) }\end{array}$ & $\begin{array}{c}\text { EGE (man } \\
\text { day/ha/day } \\
\text { ) }\end{array}$ & $\begin{array}{c}\text { Productivi } \\
\text { ty } \\
\text { (kg/ } \\
\text { ha/day) }\end{array}$ & $\begin{array}{c}\text { Net } \\
\text { return } \\
\text { (Rs./ha) }\end{array}$ & $\begin{array}{c}\text { System } \\
\text { Profitabilit } \\
\text { y } \\
\text { (Rs/ha/day } \\
\text { ) } \\
\end{array}$ \\
\hline R-W & 0.635 & 1963 & 9815 & 163.9 & 0.64 & 49.8 & 59,091 & 176.8 \\
\hline R-P-M & 0.863 & 1586 & 7930 & 173.0 & 1.18 & 67.4 & 108,262 & 216.9 \\
\hline $\mathrm{R}-\mathrm{C}-\mathrm{O}$ & 1.058 & 1080 & 5400 & 183.0 & 1.57 & 78.5 & 118,027 & 254.3 \\
\hline $\mathrm{M}-\mathrm{W}-\mathrm{M}_{\mathrm{b}}$ & 1.856 & 917 & 4585 & 241.7 & 1.21 & 81.2 & 86,410 & 374.2 \\
\hline M-P-M & 1.864 & 995 & 4975 & 260.6 & 1.41 & 88.6 & 126,689 & 346.2 \\
\hline M-P-O & 2.149 & 1215 & 6075 & 351.6 & 1.73 & 89.7 & 154,030 & 388.9 \\
\hline $\mathrm{C}_{\mathrm{h}}-\mathrm{W}-\mathrm{M}_{\mathrm{b}}$ & 1.283 & 1335 & 6675 & 232.4 & 1.68 & 79.6 & 93,721 & 229.2 \\
\hline $\mathrm{O}-\mathrm{W}-\mathrm{M}_{\mathrm{b}}$ & 1.384 & 1370 & 6850 & 270.1 & 1.25 & 71.8 & 102,142 & 288.8 \\
\hline M-G-M & 2.216 & 1190 & 5950 & 343.5 & 1.38 & 80.3 & 123,933 & 359.3 \\
\hline $\mathrm{C}_{\mathrm{p}}-\mathrm{P}-\mathrm{M}_{\mathrm{b}}$ & 2.325 & 1035 & 5175 & 315.6 & 1.65 & 83.3 & 138,050 & 328.6 \\
\hline
\end{tabular}

WUE $=$ Water use efficiency, MRUE $=$ Monetary return use efficiency, EGE $=$ Employment generation efficiency

Table.5 Soil fertility status after 5 cropping cycles (0-15 cm depth)

\begin{tabular}{|l|c|c|c|c|c|c|c|c|}
\hline Crop Sequences & $\begin{array}{c}\mathbf{N} \\
(\mathbf{k g} / \mathbf{h a})\end{array}$ & $\begin{array}{c}\mathbf{P} \\
(\mathbf{k g} / \mathbf{h a})\end{array}$ & $\mathbf{K}$ (kg/ha) & $\begin{array}{c}\mathbf{C}: \mathbf{N} \\
\mathbf{r a t i o}\end{array}$ & $\mathbf{Z n}\left(\boldsymbol{\mu g g} \mathbf{g}^{-\mathbf{1}}\right)$ & $\begin{array}{c}\mathbf{F e} \\
\left(\boldsymbol{\mu g g}^{-\mathbf{1}}\right)\end{array}$ & $\begin{array}{c}\mathbf{C u}^{-\mathbf{\mu g}} \\
\left.\mathbf{g}^{-1}\right)\end{array}$ & $\mathbf{O C}(\boldsymbol{\%})$ \\
\hline $\mathrm{R}-\mathrm{W}$ & 162.8 & 12.9 & 185.8 & 11.4 & 0.4 & 4.3 & 0.3 & 0.42 \\
\hline $\mathrm{R}-\mathrm{P}-\mathrm{M}_{\mathrm{b}}$ & 168.7 & 12.8 & 197.1 & 16.7 & 0.7 & 5.9 & 0.5 & 0.45 \\
\hline $\mathrm{R}-\mathrm{C}-\mathrm{O}$ & 177.3 & 14.4 & 200.2 & 14.1 & 0.5 & 5.4 & 0.3 & 0.47 \\
\hline $\mathrm{M}-\mathrm{W}-\mathrm{M}_{\mathrm{b}}$ & 181.0 & 13.5 & 203.2 & 14.4 & 0.9 & 4.9 & 0.4 & 0.49 \\
\hline $\mathrm{M}-\mathrm{P}-\mathrm{M}_{\mathrm{b}}$ & 181.4 & 13.2 & 206.7 & 13.6 & 0.6 & 6.6 & 0.5 & 0.53 \\
\hline $\mathrm{M}-\mathrm{P}-\mathrm{O}$ & 182.8 & 19.3 & 207.9 & 14.3 & 0.5 & 4.8 & 0.4 & 0.54 \\
\hline $\mathrm{C}_{\mathrm{h}}-\mathrm{W}-\mathrm{M}_{\mathrm{b}}$ & 172.9 & 14.6 & 198.7 & 15.6 & 0.7 & 5.1 & 0.4 & 0.51 \\
\hline $\mathrm{O}-\mathrm{W}-\mathrm{M}_{\mathrm{b}}$ & 183.7 & 14.7 & 199.6 & 12.6 & 0.7 & 5.5 & 0.4 & 0.51 \\
\hline $\mathrm{M}_{\mathrm{G}-\mathrm{M}_{\mathrm{b}}}$ & 185.7 & 23.6 & 207.7 & 13.7 & 0.6 & 6.1 & 0.5 & 0.53 \\
\hline $\mathrm{C}_{\mathrm{p}}-\mathrm{P}-\mathrm{M}_{\mathrm{b}}$ & 176.8 & 18.2 & 198.8 & 11.7 & 0.8 & 5.7 & 0.4 & 0.55 \\
\hline
\end{tabular}

\footnotetext{
Initial OC $(\%)=0.43$
} 
Table.6 Effect of alternative cropping systems on the soil enzymatic activities

\begin{tabular}{|c|c|c|c|c|c|c|c|}
\hline $\begin{array}{c}\text { Crop } \\
\text { Sequences }\end{array}$ & $\begin{array}{c}\text { Invertase } \\
\left(\mathrm{mgg}^{-1}\right)\end{array}$ & $\begin{array}{c}\text { Protease } \\
(\mu \mathrm{g})\end{array}$ & $\begin{array}{c}\text { Acid } \\
\text { Phosphatase }(\mu \mathrm{g})\end{array}$ & $\begin{array}{c}\text { Alkaline } \\
\text { Phosphatase }(\mu \mathrm{g})\end{array}$ & $\begin{array}{c}\text { Urease } \\
(\mu \mathrm{g})\end{array}$ & $\begin{array}{c}\text { Sucrase } \\
\left(\text { glucose } \mathrm{mg} \cdot \mathrm{g}^{-1}\right)\end{array}$ & $\begin{array}{c}\text { Dehydrogenas } \\
\text { e }(\mu \mathrm{g})\end{array}$ \\
\hline $\mathrm{R}-\mathrm{W}$ & 1.86 & 63.1 & 134.4 & 2553.4 & 24.4 & 59.66 & 29.2 \\
\hline R-P-M & 3.53 & 82.1 & 169.4 & 2842.9 & 26.3 & 77.46 & 45.7 \\
\hline $\mathrm{R}-\mathrm{C}-\mathrm{O}$ & 3.26 & 78.1 & 182.9 & 2862.1 & 42.7 & 57.05 & 36.9 \\
\hline $\mathrm{M}-\mathrm{W}-\mathrm{M}_{\mathrm{b}}$ & 2.80 & 86.7 & 171.4 & 2798.6 & 28.1 & 60.70 & 45.2 \\
\hline M-P-M & 3.78 & 90.4 & 183.1 & 2823.1 & 29.9 & 55.71 & 53.7 \\
\hline M-P-O & 3.81 & 105.2 & 210.6 & 2897.8 & 39.9 & 50.87 & 41.6 \\
\hline $\mathrm{C}_{\mathrm{h}}-\mathrm{W}-\mathrm{M}_{\mathrm{b}}$ & 2.36 & 119.7 & 221.1 & 3041.4 & 43.5 & 72.32 & 61.6 \\
\hline $\mathrm{O}-\mathrm{W}-\mathrm{M}_{\mathrm{b}}$ & 3.67 & 112.2 & 218.3 & 2882.8 & 44.6 & 54.22 & 62.5 \\
\hline M-G-M & 3.57 & 93.5 & 189.2 & 2930.6 & 31.8 & 47.74 & 49.2 \\
\hline $\mathrm{C}_{\mathrm{p}}-\mathrm{P}-\mathrm{M}_{\mathrm{b}}$ & 3.98 & 100.4 & 197.8 & 2908.4 & 37.3 & 44.46 & 63.8 \\
\hline
\end{tabular}

Table.7 Effect of 5 years of application of treatments on soil physical properties and total organic carbon (TOC) and soil organic carbon (SOC)

\begin{tabular}{|c|c|c|c|c|c|c|c|}
\hline \multirow[t]{2}{*}{$\begin{array}{c}\text { Crop } \\
\text { Sequences }\end{array}$} & \multirow{2}{*}{$\begin{array}{c}\text { Cation exchange } \\
\text { capacity } \\
\left(\mathrm{cmol} \mathrm{kg}^{-1}\right)\end{array}$} & \multirow{2}{*}{$\begin{array}{c}\text { Total } \\
\text { Porosity } \\
(\%)\end{array}$} & \multirow{2}{*}{$\begin{array}{c}\text { Hydraulic } \\
\text { Conductivity } \\
\left(\mathrm{mm} \mathrm{h}^{-1}\right)\end{array}$} & \multicolumn{2}{|c|}{$\begin{array}{c}\text { TOC } \\
\left(\mathrm{g} \mathrm{kg}^{-1}\right)\end{array}$} & \multicolumn{2}{|c|}{$\begin{array}{c}\text { SOC } \\
\left(\mathrm{g} \mathrm{kg}^{-1}\right)\end{array}$} \\
\hline & & & & $0-5 \mathrm{~cm}$ & $5-15 \mathrm{~cm}$ & $0-5 \mathrm{~cm}$ & $5-15 \mathrm{~cm}$ \\
\hline $\mathrm{R}-\mathrm{W}$ & 16.87 & 29.53 & 53.5 & 10.99 & 9.01 & 4.5 & 3.6 \\
\hline R-P-M $\mathrm{M}_{\mathrm{b}}$ & 17.21 & 32.65 & 48.5 & 19.64 & 15.68 & 7.9 & 6.8 \\
\hline R-C-O & 18.72 & 37.98 & 46.3 & 18.50 & 14.35 & 5.9 & 4.5 \\
\hline $\mathrm{M}-\mathrm{W}-\mathrm{M}_{\mathrm{b}}$ & 19.86 & 41.58 & 45.6 & 19.30 & 15.47 & 7.2 & 6.6 \\
\hline $\mathrm{M}-\mathrm{P}-\mathrm{M}_{\mathrm{b}}$ & 20.17 & 46.58 & 43.8 & 23.00 & 18.98 & 6.5 & 5.8 \\
\hline M-P-O & 22.04 & 54.25 & 28.9 & 25.68 & 21.63 & 9.6 & 8.3 \\
\hline $\mathrm{C}_{\mathrm{h}}-\mathrm{W}-\mathrm{M}_{\mathrm{b}}$ & 21.93 & 51.86 & 38.6 & 21.40 & 17.30 & 8.1 & 7.2 \\
\hline $\mathrm{O}-\mathrm{W}-\mathrm{M}_{\mathrm{b}}$ & 21.33 & 52.36 & 35.3 & 21.47 & 18.80 & 8.4 & 7.3 \\
\hline M-G-M & 20.89 & 49.74 & 41.6 & 23.65 & 19.08 & 8.6 & 7.6 \\
\hline $\mathrm{C}_{\mathrm{p}}-\mathrm{P}-\mathrm{M}_{\mathrm{b}}$ & 22.40 & 53.01 & 32.3 & 23.87 & 19.98 & 9.2 & 8.1 \\
\hline
\end{tabular}

EDTA-extractable micronutrients $(\mathrm{Zn}, \mathrm{Fe}$, Cu)

After completion of each cropping-cycle in 5 years' field experimentation, EDTA extractable zinc ( $\mathrm{Zn})$, iron (Fe) and copper $(\mathrm{Cu})$ were improved over initial fertility status. These micronutrients have also registered a slight improvement during the year of study over the first year status of the experimental plots irrespective of the cropping systems indicating that cowpea and mungbean residue have positive bearing on micronutrient build-up in the current study (Table 5). $\mathrm{M}-\mathrm{W}-\mathrm{M}_{\mathrm{b}}$ system registered highest magnitude of EDTA extractable $\mathrm{Zn}$ followed by $\mathrm{C}_{\mathrm{p}}-\mathrm{P}-\mathrm{M}_{\mathrm{b}}, \mathrm{O}-\mathrm{W}-\mathrm{M}_{\mathrm{b}}$, and $\mathrm{C}_{\mathrm{h}}-\mathrm{W}-\mathrm{Mb}$ system, respectively during experimentation (Table 5) while $\mathrm{M}-\mathrm{P}-\mathrm{M}_{\mathrm{b}}, \mathrm{M}-\mathrm{G}-\mathrm{M}_{\mathrm{b}}$ and R-P$\mathrm{M}_{\mathrm{b}}$ systems were the superior sequence in terms of realizing highest value of EDTA extractable $\mathrm{Fe}$ and $\mathrm{Cu}$ in soil. The maize/cowpea/chili/onion based cropping systems maintained the higher levels of zinc, iron and copper as compared to the rice-wheat cropping system (Table 5). However, all the values of micronutrients under different cropping systems were in sufficient range.

\section{Soil enzymatic activities}

The activities of all enzymes varied significantly among different alternative cropping systems. The activities of all 
enzymes were generally higher in the vegetables and pulse treatment than in the rice-wheat treatment (Table 6). The invertase activity was recorded $3.262 \mathrm{mg} \cdot \mathrm{g}^{-1}$. It can be clearly observed from the results that the enzymatic activity increased in all the alternative arable cropping system treatments as compared to rice-wheat cropping system control during study periods. Symbiotic soil microorganism activity increased with the increase in metabolism of symbiotic roots. With the increase of root exudation, microbes can release substances into soil such as humus. Soil degradation, improves the soil enzymatic activity of soil microorganisms in the soil ecosystem. Increase in the number of microbes and enhanced microbial activity improve the soil. With the decrease of temperature, soil microbial activity also decreased that leads to limits the soil enzymatic activity. After the winter season, in April when mungbean was sown, the symbiotic activity increased and $\mathrm{C}_{\mathrm{p}}-\mathrm{P}-\mathrm{M}_{\mathrm{b}}$ cropping system showed higher concentration of invertase $\left(3.98 \mathrm{mg} \cdot \mathrm{g}^{-1}\right)$ followed by M-P$\mathrm{M}_{\mathrm{b}}, \mathrm{M}-\mathrm{P}-\mathrm{O}, \mathrm{O}-\mathrm{W}-\mathrm{M}_{\mathrm{b}}, \mathrm{M}-\mathrm{G}-\mathrm{M}_{\mathrm{b}}$ and R-P-M cropping systems, however the lowest value was recorded in the R-W cropping system $\left(1.86 \mathrm{mg} \cdot \mathrm{g}^{-1}\right)$. These results are supported by (Spedding et al., 2004; Hu and Zhang, 2001) stating that microbe activity had a strong effect on soil enzymes. The soil microbial activity is an important factor for soil formulation and nutrient cycling due to their critical involvement in many soil ecosystem processes.

The activity of urease derived from Table 6 clearly depicts that with the passages of time, the activity of urease shows increasing trend in all treatments. Before alternative cropping system the urease activity was recorded 34.85 $\mu \mathrm{g}$. During experimentation rabi season, increasing trend were observed in the activity with O-W-M $\mathrm{M}_{\mathrm{b}}, \mathrm{C}_{\mathrm{h}}-\mathrm{W}-\mathrm{Mb}$, R-C-O, M-P-O and $\mathrm{C}_{\mathrm{p}}-\mathrm{P}-\mathrm{M}_{\mathrm{b}}$ cropping systems and comparatively lower value was seen in the R-W and $\mathrm{M}-\mathrm{W}$ $\mathrm{M}_{\mathrm{b}}$ cropping system. It was clear from the results that alternative cropping systems of R$\mathrm{W}$ had great influence on the activity of urease. Urease was the most prominent enzyme in the cycling of carbon and insights into the uptake of nutrients in soils as affected by land management, such as cropping systems. Many researchers described that the soil enzymes activity can be used as sensitive indicator of changes in soil biological activity and fertility in response to various soil management practices (Gajda et al., 2000; Martyniuk et al., 2001). Soil enzymes play important role in the phenomenon of soil that affects the soil fertility and soil metabolism. Plant root exudates' generates about $90 \%$ of the soil metabolic activity affecting the contents of soil enzymes directly or indirectly. Plant roots secrete extracellular enzymes and stimulants the soil microbial activity. According to Shun and Tong (2001), soil enzymatic activities are relative to trend and strength of biochemical process, which directly affect the soil productivity, ecosystem performance and economy. Urease showed close relationship with urea hydrolyzation and increase the utilization rate of nitrogen fertilizer (Klose and Tabatabai, 1999). Application of nitrogen fertilizers significantly decreased urease activity, while adding green manure increased its activity. It seems greater enzyme activities in green manure treated soil and are the key factors for more effective soil nutrient cycling mechanisms that are so critical to soil productivity, and in turn, essential to the sustainability of low-input alternative arable farming systems.

The soil alkaline phosphatase activity was 2853.21 $\mu \mathrm{g}$ before alternative arable cropping systems during the year of study. Table 6 revealed that the activity of enzyme increased after one month of alternative arable cropping systems during October in all treatments as 
compared to the R-W and $\mathrm{M}-\mathrm{W}-\mathrm{M}_{\mathrm{b}}$ cropping systems. In March 2015, alkaline Phosphatase activity was recorded at the highest level (3241.4 $\mu \mathrm{g}$ ) in $\mathrm{C}_{\mathrm{h}}-\mathrm{P}-\mathrm{M}_{\mathrm{b}}$ cropping system treatment. The activity directly influenced the decomposition of soil organic phosphorus transformation and bioavailability. The results revealed that at the time $\mathrm{C}_{\mathrm{h}}-\mathrm{W}-\mathrm{M}_{\mathrm{b}}, \mathrm{M}-\mathrm{G}-\mathrm{M}_{\mathrm{b}}$, $\mathrm{C}_{\mathrm{p}}-\mathrm{P}-\mathrm{M}_{\mathrm{b}}, \quad \mathrm{M}-\mathrm{P}-\mathrm{O}$ and $\mathrm{O}-\mathrm{W}-\mathrm{M}_{\mathrm{b}}$ cropping systems the enzymes activity were showed upward trend followed by M-P-M $\mathrm{M}_{\mathrm{b}}, \mathrm{R}-\mathrm{C}-\mathrm{O}$ and $\mathrm{R}-\mathrm{P}-\mathrm{M}_{\mathrm{b}}$ but with the passage of time the activity showed downward trend. However, the inter-treatment trend was same i.e. $\mathrm{C}_{\mathrm{h}}-\mathrm{W}$ $\mathrm{M}_{\mathrm{b}}>\mathrm{M}-\mathrm{G}-\mathrm{M}_{\mathrm{b}}>\mathrm{C}_{\mathrm{p}}-\mathrm{P}-\mathrm{M}_{\mathrm{b}}$, respectively. Alkaline Phosphatase deal with phosphorus decomposition and improve soil phosphorus validity (Pascual et al., 2002).

There were no differences in acid phosphatase activity between the $\mathrm{C}_{\mathrm{h}}-\mathrm{W}-\mathrm{M}_{\mathrm{b}}, \mathrm{O}-\mathrm{W}-\mathrm{M}_{\mathrm{b}}, \mathrm{M}-$ $\mathrm{P}-\mathrm{O}$ and $\mathrm{C}_{\mathrm{p}}-\mathrm{P}-\mathrm{M}_{\mathrm{b}}$ treatment. The protease and phosphatase activities in the $\mathrm{R}-\mathrm{W}$ treatment were significantly lower than in the $\mathrm{C}_{\mathrm{h}}-\mathrm{P}-\mathrm{M}_{\mathrm{b}}$, $\mathrm{O}-\mathrm{W}-\mathrm{M}_{\mathrm{b}}, \mathrm{M}-\mathrm{O}-\mathrm{P}$ and $\mathrm{C}_{\mathrm{p}}-\mathrm{P}-\mathrm{M}_{\mathrm{b}}$ treatments. As shown in Table 6, acid phosphatase generally increased with alternative arable cropping systems. Increased phosphatase activity could be responsible for hydrolysis of organically bound phosphate into free ions, which were taken up by plants. Plants can utilize organic $\mathrm{P}$ fractions from the soil by phosphatase activity enriched in the soil-root interface (Yosefi et al., 2011. The increases observed in enzymatic activities due to alternative arable cropping systems are in accordance with previous studies. Martens et al., (1992) reported that vegetable and pulse crops for addition of the organic matter maintained high levels of phosphatase activity in soil during a long-term study. There are several reports about soil organic matter increases resulting from legume green manuring, even without any complementary addition of FYM and compost as it is frequently prevalent in organic farm management (Drinkwater et al.,
1998). The effect of organic amendments on enzyme activities is probably a combined effect of a higher degree of enzymes stabilization to humic substances and an increase in microbial biomass with increased soil carbon concentration (Martens et al., 1992). This is also indicated by the strong correlation of protease, acid phosphatase and urease with microbial soil C concentrations (Nayak et al., 2007).

Dehydrogenase is a very useful soil enzyme as it occurs only in live cells, and it can provide an index of endogenous soil microbial activity since its assay involves no addition of a substrate that would preferentially stimulate any particular group of soil organisms. Dehydrogenase should be very useful for the assessment of soil microbial responses to green manuring because they are believed to be linked primarily with microbial activities that are associated with the initial breakdown of organic materials (Bolton et al., 1985). The activity of dehydrogenase was the lowest in $\mathrm{R}-\mathrm{W}$ cropping system and was increased by the AACS in which green manure including rotation (Table 6). Soil microbial metabolism was greatly enhanced due to legume green manure application (Elfstrand et al., 2007). Stronger dehydrogenase activity in $\mathrm{C}_{\mathrm{p}}-\mathrm{P}-\mathrm{M}_{\mathrm{b}}$, $\mathrm{O}-\mathrm{P}-\mathrm{M}_{\mathrm{b}}$ and $\mathrm{C}_{\mathrm{h}}-\mathrm{W}-\mathrm{M}_{\mathrm{b}}$ plots may be due to higher organic matter content (Wlodarczyk et al., 2002). These results were similar to our findings that dehydrogenase in rhizosphere soil of alternative arable cropping system i.e. $\mathrm{C}_{\mathrm{p}}-\mathrm{P}-\mathrm{M}_{\mathrm{b}}$ treatment was on average two times higher than that of $\mathrm{R}-\mathrm{W}$ plots (Table 6). Irrespective of $\mathrm{AACS}, \mathrm{C}_{\mathrm{P}}-\mathrm{P}-\mathrm{M}_{\mathrm{b}}$ sequence showed sizable increment in enzymatic activities might be due to exudation of organic substances from root biomass especially legumes which act as substrate to soil microbes, and thus, encourage the dehydrogenase activity and microbial population in the soil. 


\section{Cation exchange capacity}

Cation exchange capacity (CEC) was also increased due to alternative arable cropping systems. The highest CEC increase under alternative arable cropping systems (32.8\%) was found in $\mathrm{C}_{\mathrm{p}}-\mathrm{P}-\mathrm{M}_{\mathrm{b}}$ followed by $\mathrm{M}-\mathrm{P}-\mathrm{O}$ $(30.6 \%)$ and $\mathrm{C}_{\mathrm{h}}-\mathrm{W}-\mathrm{M}_{\mathrm{b}} \quad(29.9 \%)$. $\mathrm{R}-\mathrm{W}$ cropping system showed the lowest increase of CEC from the experimentation (Table 7).The large loss of aggregate stability for the $\mathrm{R}-\mathrm{W}$ system is of particular concern, as it suggests that the increased aggregate stability of surface soil under R-W is due to puddling rather than an intrinsic property of $\mathrm{R}-\mathrm{W}$ cropping system. This observation is consistent with that of Hammer beck et al., (2012).

\section{Total porosity and hydraulic conductivity}

Soil porosity results showed that alternative arable cropping systems plots could increased the total porosity of soil, while R-W cropping system would decrease the soil porosity for aeration; as a result, it enhances the water holding capacity of soil along with bad aeration of soil.

However, the effects of alternative arable cropping systems on the total porosity were significant. Alternative arable cropping systems plots shown an improvement in the soil porosity and was most probably related to the beneficial effects of soil organic matter caused by residue cover (Table 7). Oliveira and Merwin, 2001 found that the increased porosity was especially important for the crop development since it may have a direct effect on the soil aeration and enhances the root growth. The improved root growth would hence increase plant water as well as nutrient uptake. Within the alternative arable cropping systems, M-P-O, $\mathrm{C}_{\mathrm{p}}-\mathrm{P}-\mathrm{M}_{\mathrm{b}}, \mathrm{O}-\mathrm{W}-\mathrm{M}_{\mathrm{b}}, \mathrm{C}_{\mathrm{h}}-\mathrm{W}-$ $\mathrm{M}_{\mathrm{b}}$, M-G-M $\mathrm{M}_{\mathrm{b}}$, and M-P-M $\mathrm{M}_{\mathrm{b}}$ produced more porosity than R-W cropping system. Husnjak and Kosutic (2002); Naresh et al., (2014) reported that higher $\mathrm{BD}$ reduced the total porosity and changed the ratio of water holding capacity to air capacity in favour of water holding capacity.

\section{Soil organic carbon (SOC)}

Results of alternative arable cropping systems after five years significantly influenced the total organic carbon (TOC), and soil organic carbon (SOC) content of the surface soil is depicted in (Table 7). Data indicate that R-W cropping system have a resulted in highly significant losses of SOC ranging from 5.94 to $8.47 \%$ for both the $0-5$ and $5-15 \mathrm{~cm}$ depths. In surface soil (0-5 cm layer) highest soil organic carbon change (12.68\%) was found in $\mathrm{M}-\mathrm{P}-\mathrm{O}$ cropping system plots followed by $\mathrm{C}_{\mathrm{p}}-\mathrm{P}-\mathrm{M}_{\mathrm{b}}$ cropping system plots $(11.89 \%)$.The adoption of alternative arable cropping systems of M-P-O and $\mathrm{C}_{\mathrm{p}}-\mathrm{P}-\mathrm{M}_{\mathrm{b}}$ for five crop cycle increased soil organic carbon by $53.12 \%$ and $51.09 \%$ more than that of R$\mathrm{W}$ cropping systems, respectively.

These treatments were statistically similar and significantly higher from all other treatments. Irrespective of alternative arable cropping systems in $0-5 \mathrm{~cm}$ soil layer enhanced $55.9 \%$ and $63.2 \%$ TOC and SOC, respectively, in surface soil as compared to R-W cropping system. Similar increasing trends were observed in $5-15 \mathrm{~cm}$ soil layer, however, the magnitude was relatively lower (Table 7). The higher content of SOC in the surface soil is because the organic matter is usually incorporated in the surface layer and left over residues of shallow-rooted crops like mungbean and cowpea also gets accumulated in the top few centimeters of the soil Naresh et al., 2015.

Our study corroborates that $\mathrm{M}-\mathrm{P}-\mathrm{O}$; cropping systems proved as an alternate viable option in realizing higher crop productivity, 
enzymatic activities production efficiency, energy relationships and nutrition as the result of improved resource use efficiency without deteriorating soil physicochemical and microbiological properties rather being vital for $\mathrm{OC}$ restoration, nutrient turnover and soil health. M-P-M $\mathrm{M}_{\mathrm{b}}$ cropping system was found second better alternative with respect to above production parameters and soil health indices. Overall, high-value crops imbedded $\mathrm{C}_{\mathrm{p}}-\mathrm{P}-\mathrm{M}_{\mathrm{b}}$ and $\mathrm{M}-\mathrm{G}-\mathrm{M}_{\mathrm{b}}$ systems may prove as best AACS for enhancing productivity, profitability, nutrient recycling and long-term soil fertility in the subtropical climatic condition of western Uttar Pradesh, India.

This research offered an orientation towards alternative arable cropping strategies model with regard to its evaluation and implication dimensions and it can help achieving sustainability of farms depending on the nature of the resources available for farmers and promote food security in the region. Nevertheless, there is a need for more quantitative assessment of the productivity potential of alternatively arable cropping systems of subtropical climatic condition of western Uttar Pradesh, India under different management practices for different soil types, climates and agricultural systems by supporting existing long term cropping system trial sites and the establishment of new ones where appropriate; quantifying interactions of resource use efficiency and developing farm profitability models that can account for locally relevant agricultural management practices.

\section{Acknowledgments}

Authors are grateful to the authorities of the Sardar Vallabbhai Patel University of Agriculture and Technology, Meerut, U.P., India for all support in execution of this experiment. We also acknowledge the technical support from. Moreover, we would like to express our great respect for the editors and anonymous reviewers to improve the manuscript quality.

\section{References}

Anderson R.I. 2005. Are some crops synergistic to following crops? Agron J 97(1): 7-10

Banik P. and Sharma R.C. 2009. Effect of organic and inorganic sources of nutrients on the winter crops-rice cropping system in sub-humid tropics of India. Arch Agron Soil Sci 55:285-294

Bastia D.K., Garnayak L. M. and Barik T. K. 2008. Diversification of rice (Oryza sativa) wheat (Triticum aestivum) based cropping systems for higher productivity, resource use efficiency and economics. Indian J Agron 53 (1): 22-26.

Bohra J.S., Singh R.K., Singh U.N., Singh Kalyan and Singh R.P. 2007. Effect of crop Diversification in rice-wheat cropping system on productivity, economics, land use and energy use efficiency under irrigated ecosystem of Varanasi. Oryza, 44 (4): 320-324.

Bolton J., Elliott L. F., Papendick P.R. and Bezdicek D.F. 1985. Soil microbial biomass and selected soil enzyme activities: effect of fertilization and cropping practices. Soil Biol Biochem 17: 297-302.

Bouyoucos G.J. 1962. Hydrometer method improved for making particle size analysis of soils. Agron J 54:464-465

Cassman K.G., Olk D.C., Brouder S.M. and Roberts B.A. 1995. The influence of moisture regime, organic matter and root ecophysiology on the availability and acquisition of potassium: implications for tropicallowland rice. In: Potassium in Asia. Proceedings of the 24th International Colloquium of the International Potash Institute. International Potash Institute, Basel, pp. $135-156$.

Chandrappa H., Prabhakara B.N., Mallikarjuna G.B. and Denesh G.R. 2005. 
Identification of efficient, employment generative and profitable cropping systems for southern transitional zone of Karnataka. Indian Agri Sci 75 (8): 490-92

Chopra SL and Kanwar JS.1991. Analytical agriculture chemistry, $4^{\text {th }}$ edn. Kalyani Publishers, New Delhi, p 301

Choudhary A.K. and Suri V.K. 2014. Integrated nutrient management technology for direct seeded upland rice (Oryza sativa) in NW Himalayas. Commun Soil Sci Plant Anal 45:777-784

Choudhary A.K., Thakur S.K. and Suri V.K. 2013. Technology transfer model on integrated nutrient management technology for sustainable crop production in high value cash crops and vegetables in north-western Himalayas. Commun Soil Sci Plant Anal 44:16841699

Dey B., Singh M.K., De C., Singh V.K. and De N. 2012. Economic analysis on chilli production in the Gangetic alluvial soil. Inter J Agric Environ Biotech 5:31-34

Dwivedi B.S., Shukla A.K., Singh V.K. and Yadav R.L. 2001. Results of participatory diagnosis of constraints and opportunities (PDCO) based trials from the state of Uttar Pradesh. In: Subba Rao, A., Srivastava, S. (Eds.), Development of Farmers' Resource Based Integrated Plant Nutrient Supply Systems: Experience of a FAO-ICAR-IFFCO Collaborative Project and AICRP on Soil Test Crop Response Correlation. IISS, Bhopal, India, pp. 50-75

Dwivedi B.S., Shukla A.K., Singh V.K. and Yadav R.L. 2003. Improving nitrogen and phosphorus use efficiencies through inclusion of forage cowpea in the ricewheat systems in the Indo-Gangetic plains of India. Field Crops Res 84:399418

Elfstrand S., Ba B., and Rtensson M. 2007. Influence of various forms of green manure amendment on soil microbial community composition, enzyme activity and nutrient levels in leek. Appl Soil Ecol 36: $70-82$.
Gajda A., Martyniuk S., Stachyra A., Wroblewska B. and Zieba S. 2000. Relations between microbiological and biochemical properties of soil under different agro-technical conditions and its productivity. Polish.J. Soil Sci., 33: 55

Gangwar B. and Ram Baldev. 2005. Diversification Opportunities in ricewheat cropping. In Alternative Farming System Edited by Singh A. K., Gangwar B and Sharma S.K. 2005 FSRDA, PDCSR, Modipuram, Meerut :154-162

Gill M.S. and Ahlawat I.P.S. 2006. Crop diversification and its role towards sustainability and profitability. Indian $J$ Ferti 2 (9): 125-138

Gill M.S. and Sharma G.C. 2005. Cropping system diversification opportunities and conservation agriculture. J.Farming Systems Research \& Development. 11(2): 127-134

Gomez KA, Gomez AA. 1984. Statistical procedures for agricultural research. Second Edition, An international rice research institute book. Wiley-InterScience Publication, Wiley, New York

Gopalan C, Sastri B. V. R. and Balasusbramanium S. C. 1978.Nutritive value of Indian Food. pp 66-144.National Institute of Nutrition Indian Council of Medical Research Hyderabad, Andhra Pradesh.

Guan S.Y. 1986. Soil Enzyme and Study Methods of Soil Enzyme. Beijing: Agriculture Publication House

Guan S.Y. 1989. Studies on the factors influencing soil enzyme activities. Acta Pedologica Sin., 26: 72-78

Guan S.Y. and Shen G.Q. 1984. Enzyme activities in main soil in China. Acta Pedologica Sin., 21: 368-381

Gupta R.P. 2013. Onion production: Challenges and ways to meet out the demand of the country, India. In: Holmer R, Linwattana G, Nath P, Keatinge JDH (eds) Proceedings of regional symposium on high value vegetables in southeast Asia: production, supply and demand. AVRDCWorld Vegetable Centre, Publication No. 
12-758, pp 124-134

Hammer beck A.L., Stetson S.J., Osborne S.L., Schumacher T.E. and Pikul Jr., J.L.2012. Corn residue removal impact on soil aggregates in a no-till corn/soybean rotation. Soil Sci Soc Am J., 4: 1390 1398

Hanway J.J. and Heidel H. 1952. Soil analysis methods as used in Iowa State College Soil Testing Laboratory, Bulletin 57. Iowa State College of Agriculture, USA, $\mathrm{p} 131$

Hegde D.M., Prakash Tiwari S. and Rai M. 2003. Crop diversification in Indian Agriculture Agricultural Situation in India. August, 2003. pp. 351-354.

$\mathrm{Hu}$ H.B. and Zhang J.C. 2001. Study on soil enzyme activity of main forest types in rock coastal area. J. Nanjing For. University, 25: 21-25

Husnjak S., filipovic D. and Kosutic S. 2002. Influence of different tillage systems on soil physical properties and crop yield. Rostlinna Vyroba, 48 (6): 249-254.

Idnani L. K. and Singh Raman Jeet. 2008. Effect of irrigation regimes, planting and irrigation methods and arbuscular mycorrhizae on productivity, nutrient uptake and water use in summer green gram (Vigna radiata var radiata) Indian $J$ Agri Sci 78: 53-57.

Jackson M.L. 1967. Soil chemical analysis. Prentice Hall of India Ltd, New Delhi, pp 219-221

Kalia P.K. and Kumar R. 2012. Agrotechniques for vegetable production. Indian Agricultural Research Institute Publication No. ICN-H-110/2012, pp 155

Katyal V. and Gangwar B. 2011.Statistical Methods for Agricultural Field Experiments. P 89.New India Publisingh Agency, Pitampura, New Delhi, India.

Klose S. and Tabatabai M.A. 1999. Urease activity of microbial biomass in soils. Soil Biol. Bioch., 31: 205-211

Kumar Alok, Tripathi H.P., Yadav R.A. and Yadav D.S. 2008. Diversification of rice (Oryza sativa) - wheat (Triticum aestivum) cropping system for sustainable production in eastern Uttar Pradesh. Indian J. Agron. 53 (1): 18-21.

Ladd J.N. and Butler J.H.A.1972. Short-term assays of soil proteolytic enzyme activities using proteins and peptide derivates as substrates. Soil Biol Biochem. 4:19-30.

Lindsay W.L. and Norvell W. 1978. Development of a DTPA soil test for zinc, iron, manganese and copper. Soil Sci Soc Am J. 42:421-428

Lund Z.F. and Doss B.D. 1980. Residual effects of dairy cattle manure on plant growth and soil properties. Agron J 72:123-130

Mandal A., Patra A.K., Singh D., Swarup A. and Masto R.E. 2007. Effect of long-term application of manure and fertilizer on biological and biochemical activities in soil during crop development stages. Biores Technol 98: 3585-3592.

Mandal K.G., Saha K.P., Hati K.M., Singh V.V., Misra A.K., Ghosh P.K. and Bandyopadhyay K.K. 2005. Cropping systems of central India: an energy and economic analysis. J Sustain Agric 25: $117-140$

Martens D.A., Johanson J.B. and Frankenberger J.W.T. 1992. Production and persistence of soil enzymes with repeated addition of organic residues. Soil Sci 153: 53-61.

Martinez V.A., Rowland D., Sorensen R.B. and Yeater K.M.2008. Microbial community structure and functionality under peanutbased cropping systems in a sandy soil.

Biol. Fert. Soils, 44: 681-692.

Martyniuk S., Gajda A.and Kuś J. 2001. Microbiological and biochemical properties of soil under cereals grown in the ecological, conventional and integrated systems. Acta Agro.Physica, 52: 185

Naresh R.K., Dhaliwal S.S.,Kumar D., Tomar,S.S.,Misra, A.K.,Singh S.P., Kumar, P., Kumar V. and Gupta R. K. 2014. Tillage and Rice-Wheat Cropping Systems Influences on Soil Physical Properties; water balance and Wheat Yield under Irrigated Conditions. AJAR; 9 
(32): 2463-2474

Naresh R.K.,Gupta Raj K., Gajendra Pal, Dhaliwal S.S., Kumar Dipender, Kumar Vineet, Arya Vichitra Kumar, Raju, SinghS.P., Basharullah and Singh Onkar. 2015. Tillage Crop Establishment Strategies and Soil Fertility Management: Resource Use Efficiencies and Soil Carbon Sequestration in a Rice-Wheat Cropping System. Eco Environ Con. 21: 121-128

Öhlinger R., Phosphomonoesterase activity with the substrate phenylphosphate. In: Schinner, F., Öhlinger, R., Kandeler, E., Margesin, R., (eds.) Methods in Soil Biology, 1996, pg. 210-213. Springer, Berlin.

Oliveira M.T. and Merwin I.A.2001. Soil physical conditions in a New York orchard after eight years under different groundcover management systems. Plant and Soil 234: 233-237

Olsen S.R., Cole C.V., Watanabe F.S. and Dean L. 1954. Estimation of available phosphorus in soil by extraction with sodium carbonate. USDA, Washington, $\mathrm{p}$ 933

Pascual J.A., Moreno J.L. and Hernandez T. 2002. Persistence of immobilized and total urease and phosphatase activities in a soil amended with organic wastes. Bioresour. Technol., 82: 73-78

Ponnamperuma FN. 1972. The chemistry of submerged soils. Adv. Agron. 24, 29-96.

Pooniya V., Shivay Y.S., Rana A., Nain L. and Prasanna R. 2012.Enhancing soil nutrient dynamics and productivity of basmati rice through residue incorporation and zinc fertilization. Eur J Agron 41:28-37

Reddy B.N. and Suresh G. 2009. Crop diversification with oilseed crops for maximizing productivity, profitability and resource conservation. Indian J Argon 54 (2): 206-214.

Samuel A.D. and Kiss S. 1999. The effects of soil management practices on the enzymatic activities in a brown luvic soil stud. Univ. Babeş- Bolyai, Biol., 44, 1999, pg. 189-19
Serra-Wittling C., Houot S. and Barriuso E.1995. Soil enzymatic response to addition of municipal solid-waste compost. Biol Ferti Soils 20: 226-236.

Sharma A.K., Thakur N.P., Koushal Sanjay and Kachroo Dileep. 2007. Profitable and energy efficient rice-based cropping system under subtropical irrigated conditions of Jammu. In: Extended summaries 3rd National Symposium on Integrated Farming Systems, October 2628, 2007 organized by Farming System and Development Association (Project Directorate for Cropping System Research, Modipuram, Meerut) at Agricultural Research Station, Durgapura, Jaipur.

Sharma B.R. 2002. Efficient conservation and management of water resources for sustainable agriculture. Indian Farming 52 (8): 66-70.

Sharma P.K. and De Datta S.K. 1986. Physical properties and processes of puddled rice soils. Adv. Soil Sci. 5, 139-178.

Sharma S.K. and Sharma S N. 2005. Effect of crop diversification of rice-wheat cropping system on productivity and profitability. J Sustain Agric 26:39-48

Sharma S.N. and Sharma S.K. 2004. Role of crop diversification and integrated nutrient management in resilience of soil fertility under rice-wheat cropping system. Arch Agro Soil Sci 50:345-352

Singh G. 2012. Agriculture diversification options for climate resilient agriculture and livelihood securities. In: Proceedings of $3^{\text {rd }}$ international agronomy congress on agricultural diversification, climate change management and livelihoods, vol I. New Delhi, India, pp 19-21

Singh H.P. and Malhotra S.K. 2013. Trend of horticultural research particularly vegetables in India and its regional prospects. pp 321-343. In: Holmer R, Linwattana G, Nath P, Keatinge JDH (eds) Proceedings of regional symposium on high value vegetables in Southeast Asia: production, supply and demand. AVRDCWorld Vegetable Centre, 
Taiwan. Publication No. 12, pp 758

Singh R. P., Das S. K., Bhaskara Rao V. M. and Narayana Reddy M. 1990. Towards sustainable dryland agricultural practices, pp5-8. Central Research Institute for Dryland Agriculture, Hyderabad.

Singh R.K.,Bohra J.S.,Nath T.,SinghY. and Singh K.2011.Integrated assessment of diversification of rice-wheat cropping system in Indo-Gangetic plain. Arch Agron Soil Sci 57:489-506

Snyder D. and Trofymow J.A. 1984. Rapid accurate wet oxidation diffusion procedure for determining organic and inorganic carbon in plant and soil samples. Comm. Soil Sci. Plant Anal. 15, 1587-1597.

Spedding T.A., Hamel C., Mehuys G.R. and Madramootoo C.A. 2004. Soil microbial dynamics in Maize-growing soil under different tillage and residue management systems. Soil Biol. Biochem., 36: 499-512

Subbiah B.V. and Asija G.L. 1956. A rapid procedure for assessment of available nitrogen in rice soils. Curr Sci 25:259260

Tripathi R.P. 1992. Physical properties and tillage of rice soils in rice-wheat system. In: Pandey, R.K., Dwivedi, B.S., Sharma,
A.K. (Eds.), Rice-wheat Cropping System. PDCSR, Modipuram, India, pp. 53-67

Walkley A.J.and Black I.A. 1934. An examination of the Dagtjareff method for determination of soil organic matter and a proposed modification of the chromic acid titration method. Soil Sci 37: 29-38

Wlodarczyk T., Stepniewski W. and Brzezinska M. 2002. Dehydrogenase activity, redox potential, and emissions of carbon dioxide and nitrous oxide from Cambisols under flooding conditions. Biol Fert Soils 36: 200-206.

Yadav J.S.P. 2002. Agricultural resource management in India: the challenges. $\mathbf{J}$ Agri Water Manag 1(1):61-69

Yadav R.L. 1998. Factor productivity trends in a rice-wheat cropping system under long -term use of chemical fertilizers. Exp. Agric. 34, 1-18.

Yosefi K., Galavi M., Ramrodi M. and Mousavi S.R. 2011. Effect of bio-phosphate and chemical phosphorus fertilizer accompanied with micronutrient foliar application on growth, yield and yield components of maize (Single Cross 704). Aust J Crop Sci 5 (2):175-180.

\section{How to cite this article:}

Naresh, R.K., Ashok Kumar, Mukesh Kumar, Vivek, P.K. Singh, Manoj Kumar Singh, S.P. Singh and Vivak Ujjwal. 2017. Alternative Arable Cropping Strategies: A Key to Enhanced Productivity, Resource-Use-Efficiency, and Soil-Health under Subtropical Climatic Condition. Int.J.Curr.Microbiol.App.Sci. 6(11): 1187-1205. doi: https://doi.org/10.20546/ijcmas.2017.611.142 